\title{
A diákok gondolkodásának fejlődése a történelemtanulás eredményeként
}

Felkelteni a múlt iránti érdeklódést, új dolgok megismerésére és önálló gondolkodásra ösztönözni a fiatalokat soha meg nem unható

kihívás. Ez az írás azoknak a történelemtanároknak szól, akik kiválóan ismerik a történelmet, de ezzel nem elégszenek meg. Azt is meg akarják érteni, hogy mi játszódik le a diákok fejében, miközben

történelmet tanulnak, mert ennek ismerete is szükséges az eredményes tanításhoz.

\section{A múltról szóló történetek, magyarázatok és viták bemutatása a diákoknak}

\footnotetext{
$\mathrm{P}$
} eter Lee, az Institute of Education University of London professzora 2005-ben munkatársaival közösen amellett érvelt, hogy a történelemtanítás részévé kell tenni a múltra vonatkozó interpretációk kritikus összehasonlítását is (Lee, Ashby és Shemilt, 2005). Kiindulópontjuk szerint a helyes történelemszemlélet alapja, hogy a tanulók a múltról szóló ismertetéseket és magyarázatokat ('account') annak lássák, amik: ne a múlt pontos másolatainak, hanem történészek által készített konstrukcióknak. Mégpedig olyan konstrukcióknak, amelyek csak azokra a kérdésekre próbálnak érvekkel és forrásokon alapuló bizonyítékokkal választ adni, amiket a történész az általa választott téma szempontjából fontosnak tartott. A múlt értelmes vizsgálatának ugyanis mindig előfeltétele a téma lehatárolása és az ehhez kapcsolódó kérdések előzetes megfogalmazása.

A múltról szóló történetek és a történelmi magyarázatok nem a múlt reprodukciói. Soha nem képesek minden részletet bemutatni, mégis többek, mint a feltárt vagy megörzött részletek egyszerű halmazai. Összerendezik és értelmet adnak a múltnak, mert összefüggéseket teremtenek a lejátszódott események között, bár egyáltalán nem biztos, hogy a dolgok tényleg úgy kapcsolódtak egymáshoz a valóságban.

Mindezek megértése szükséges ahhoz, hogy a diákok helyesen tudják értelmezni és kezelni az egymásnak ellentmondó vagy egymástól eltérő következtetéseket és véleményeket. Ez már csak azért is fontos, mert bármiröl is tanulnak a diákok az iskolában, nagy valószínüséggel találkozni fognak az ott megismert értelmezésektől és véleményektől eltérö interpretációkkal is otthon, a környezetükben vagy a médiában. A múltra vonatkozó eltérő vélemények összehasonlítására és értékelésére ilyen értelemben mindenkinek szüksége van a mindennapi életben is.

Az iskolának eszközöket kell adni ahhoz, hogy a diákok az eltérő történelmi interpretációkból fakadó viták értelmes és kritikus olvasóivá váljanak. Meg kell tanítani nekik, hogy miként lehet ellenőrizni egy állítás megalapozottságát. Gyakoroltatni kell az állításokhoz tartozó érvek és bizonyítékok kritikus értékelését, illetve a probléma kapcsán feltett kérdések relevanciájának összehasonlítását. Ha nem szereznek tapasztalatokat a 
diákok arról, hogy a történelmi állítások hitelességét és megbízhatóságát is ellenőrizni lehet, a múltról folyó viták és az egymással versengő vélemények bemutatása a történelmi gondolkodás fejlesztése helyett a történelmi relativizmus hamis szemléletét alakíthatja ki bennük.

\section{A tanulók gondolkodásának fejlődése a történelmi interpretációkkal kapcsolatban}

A kutatások azt mutatják, hogy a tanulók kezdetben csak akkor fogadnak el egy múltról szóló beszámolót igaznak, ha úgy gondolják, hogy annak minden egyes részlete is igaz (Lee és mtsai, 2005). Vagyis a történelmi beszámolók értékelésekor is az igaz-hamis mindennapi életben érvényes értelmezését próbálják meg használni (Lee és $A s h b y$, 2000). Sokszor okoz problémát az is, hogy a történészek által konstruált történeteket és ismertetéseket a történelmi valóság reprodukcióiként kezelik, amelyek minden részletükben és teljesen megfelelnek annak, ami a múltban történt. Ebből fakad az a véleményük is, hogy ha két történész véleménye eltér, ez csak azért lehet, mert az egyikük valamit nem jól tud (Lee és mtsai, 2005). Látható, hogy a mindennapi életben jól müködő gondolkodásmód minden fenntartás nélküli alkalmazása a történelemtanulásban többféleképpen is tévútra viheti őket.

Érettebb gondolkodást tükröz, amikor diákok a történelmi múlt kutatását egy mozaik kirakásaként képzelik el, ahol egy-egy újabb mozaik megtalálása viheti közelebb a történészeket az igazsághoz. Ebből persze az a téves elképzelés is következhet, hogy amíg nem találunk meg egy újabb forrást, nincs is esély arra, hogy pontosabb képet alkossunk a múltról (Lee és mtsai, 2005). Idősebb korban a tanulók felismerik az előítéletek és a szándékos hazugságok torzító hatását a forrásokban és a később készült interpretációkban egyaránt, sőt hajlamossá válnak ilyen okokkal megmagyarázni minden egymással ellentétes állítást és véleményt. Ebből pedig arra a hamis következtetésre jutnak, hogy minél semlegesebb a forrás vagy a történelmi interpretáció szerzőjének a nézőpontja, annál megbízhatóbbnak tekinthető az, amit állít. És ugyanilyen téves módon a helyes tudományos következtetések legfőbb kritériumának is az értékmentes és semleges nézőpontú megközelítést gondolják (Barca, 1997).

A kutatások azt mutatják, hogy a tanulók kezdetben csak akkor fogadnak el egy múltról szóló beszámolót igaznak, ha úgy gondolják, hogy annak minden egyes részlete is igaz (Lee és mtsai, 2005). Vagyis a történelmi beszámolók értékelésekor is az igaz-hamis mindennapi életben érvényes értelmezését próbálják meg használni (Lee és Ashby, 2000). Sokszor okoz problémát az is, hogy a történészek által konstruált történeteket és ismertetéseket a történelmi valóság reprodukcióiként kezelik, amelyek minden részletükben és teljesen megfelelnek annak, ami a múltban történt. Ebból fakad az a véleményük is, hogy ha két történész véleménye eltér, ez csak azért lehet, mert az egyikük valamit nem jól tud (Lee és mtsai, 2005). Látható, hogy a mindennapi életben jól múködó gondolkodásmód minden fenntartás nélküli alkalmazása a történelemtanulásban

többféleképpen is tévútra viheti óket. 
Általában csak a középiskolai történelemtanulás vége táján, és csak a legjobb tanulók jutnak el annak a felismeréséig, hogy a történelmi beszámolók viszonylagos értékessége összehasonlítható abból a szempontból is, hogy milyen kérdésekre keressünk választ a segítségükkel (Lee és mtsai, 2005). Ha egy tanuló megérti, hogy a történelemről szóló beszámolók nem a múlt másolatai, hanem olyan emberek múvei, akik meghatározott témákról általuk megfogalmazott kérdésekre igyekeztek választ adni, az is egyre világosabbá válik a számára, hogy az egymástól eltérő hiteles interpretációk kiegészíthetik egymást, és a bennük fellelhető különbségek nem gyengítik, inkább erősítik a történettudományt.

\section{Tájékozódási pontok a történelmi időben}

A múlt eseményei közötti eligazodás meglehetősen nehéz feladat a tanulók számára. Egy speciális mentális térképet kell magukban kialakítani, amelyben az egyes korok és korszakok az eseményeket összekötő útvonalak, a történelmi fordulópontok pedig az elágazások.

A történelemben az események időpontjának és a korszakok hosszának meghatározásához konvencionális időszámítási rendszert használunk (dátumok, évek, évtizedek, évszázadok, évezredek). Alkalmazzuk azokat a fogalmakat is (pl. emberöltő, generáció), amelyek az emberi élet hosszához viszonyítva adnak támpontot az eltelt idő tartamáról. A kiemelkedő események dátumainak ismerete is fontos az események közötti időrend és időbeli távolság helyes érzékeléséhez.

Az első fontos dolog, amit a diákoknak meg kell érteni, hogy a történészek az időmeghatározás konvencionális eszközeit használják, de nem naptári évek szerint tagolják az időt. A középkori krónikákat egyebek mellett azért sem tekintjük valódi történetírásnak, mert szerzőik egyszerüen csak feljegyezték, ami egy adott évben történt. A valódi történelemkönyvekben az eseményeket, folyamatokat és tényeket a történészek az általuk megállapított összefüggések és az általuk választott szempontok szerint sorolják egy-egy korszakba. Ezek kezdete és vége pedig szinte sohasem esik egybe egy-egy új évszázad kezdő és záró dátumával. Még akkor is így van ez, ha például valamire azt mondjuk, hogy jellemzően 19. századi. Ilyenkor is biztosak lehetünk abban, hogy valami olyan dologról van szó, amely már vagy a század kezdete előtt is megjelent, vagy még utána is létezett, vagy csak a század egy rövidebb időszakára volt jellemző, de sohasem valami olyanról, ami éppen a század kezdetétől a végéig tartott. A diákoknak látniuk kell, hogy ilyen értelemben egyáltalán nem abszurd az a történelmi kérdés, hogy mikor is kezdődött a 19. század.

Az időbeli kezdet és vég meghatározása a történelmi események által meghatározható korszakok esetében sem mindig egyértelmü. A tanítás során erre a legjobb példát a Római Birodalom bukásának időpontja körüli vita szolgáltatja. Van, aki a bukást már jóval a hagyományosan elfogadott 476 előttre helyezi, míg mások szerint a Keletrómai Birodalom nagyon is létezett még ezután is, tehát a Római Birodalom története nem ért még véget ekkor. Nyilvánvaló, hogy ez a vita nem a dátumokról folyik elsősorban, hanem sokkal inkább arról, hogy ki mit tekint a Római Birodalom lényegének, milyen kritériumok alapján definiálja azt, amit a történelem Római Birodalomnak nevez. Amikor tehát ezt a vitát a tanulóinknak bemutatjuk, nagyon sok olyan kérdéssel is szembesülhetnek, amely a történelemszemléletüket is formálhatja, és felhívja a figyelmüket a korszakok meghatározásának egész problematikájára.

Nemcsak a korszakok időhatárainak megállapítása, hanem a korszakok elnevezése is a történész interpretációján alapul. Kezdve azzal, hogy a múlt egészéből mit hasít ki térben, időben és tartalomban (pl. világtörténelem vagy nemzeti történelem, müvelödéstörténet vagy politikatörténet), aztán pedig, hogy a korszakolás szempontjából mit tekint 
lényeges folyamatnak, és hol határozza meg ennek fordulópontjait. Mindez együtt határozza meg, hogy hány korszakot különít el, és hogy a korszakok megnevezése tárgyszerü lesz, vagy valamilyen értékítéletet is tükröz. Természetesen a történész felfogására jelentős hatást gyakorol az a korszak is, amelyből visszatekintve vizsgálja a múltat. A magyar történelem egészének bemutatására vállalkozó 19. századi és 21 . századi történelmi mü tartalomjegyzékének egymás mellé állításával nagyon jól tudjuk a diákjainknak illusztrálni e különbségeket.

Szilágyi Sándor: A Magyar Nemzet Története ${ }^{1}$

MAGYARORSZÁG A KIRÁLYSÁG MEGALAPITÁSÁIG

MAGYARORSZÁG TÖRTÉNETE AZ ÁRPÁDOK KORÁBAN (1038-1301)

AZ ANJOUK KORA AZ ANJOU HÁZ ÉS ÖRÖKÖSEI (1301-1439)

A HUNYADIAK ÉS A JAGELLÓK KORA (1440-1526)

MAGYARORSZÁG HÁROM RÉSZRE OSZLÁSÁNAK TÖRTÉNETE (1526-1608)

MAGYARORSZÁG TÖRTÉNETE II. MÁTYÁSTÓL III. FERDINÁND HALÁLÁIG

MAGYARORSZÁG TÖRTÉNETE I. LIPÓT ÉS I. JÓZSEF KORÁBAN (1657-1711)

MAGYARORSZÁG TÖRTÉNETE A SZATMÁRI BÉKÉTÖL A BÉCSI CONGRESSUSIG $1711-1815$

A NEMZETI ÁLLAMALKOTÁS KORA (1815-1847)

A MODERN MAGYARORSZÁG (1848-1896)

Magyarország története, 1-24. kötet (föszerkesztő: Romsics Ignác)²

1. Östörténet és honfoglalás

2. Államalapítás 970-1038

3. Válság és megerősödés 1038-1196

4. Nagy uralkodók és kiskirályok a 13. században

5. Az Anjouk birodalma 1301-1387

6. Luxemburgi Zsigmond uralkodása 1387-1437

7. A Hunyadiak kora 1437-1490

8. Mohács felé 1490-1526

9. A három részre szakadt ország 1526-1606

10. Romlás és megújulás $1606-1703$

11. A Rákóczi-szabadságharc 1703-1711

12. Megbékélés és újjáépítés 1711-1790

13. A nemzeti ébredés kora 1790-1848

14. Forradalom és szabadságharc 1848-1849

15. Polgári átalakulás és neoabszolutizmus 1849-1867

16. A dualizmus kora 1868-1914

17. Világháború és forradalmak 1914-1919

18. A Horthy-korszak 1920-1941

19. Magyarország a második világháborúban

20. Demokráciából a diktatúrába 1945-1956

21. Az 1956-os forradalom és szabadságharc

22. A Kádár-korszak 1956-1989

23. A Harmadik Magyar Köztársaság 1989-2009

24. Időrendi áttekintés 
A tanítás során azt is figyelembe kell vennünk, hogy a történelmi korszakok nevei által felidézhető tudás megszerzése nem egyszerü feladat. Amikor azt olvassuk például, hogy a dualizmus kora, ennek megértése és helyes értelmezése egy adott szövegkörnyezetben pontosan nehezen körülírható elözetes tudást igényel. Az ilyen típusú történelmi fogalmak használatához nem elég egy definíciót megtanulnunk, hanem nagyon sokféle eseményből és ismeretelemből álló háttérismeretet kell birtokolnunk, amelyből aztán mindig az adott helyzetnek megfelelő vonatkozást kell tudnunk felidézni. Ez viszont azt is jelenti, hogy maguk a korszakok nagyon hasznos tematikus szervezői a történelmi ismereteknek. Ezért az ismeretanyag korszakonkénti elrendezése rendkívül fontos feltétele a nagy mennyiségű tényanyag megjegyzésének, felidézhetőségének és alkalmazhatóságának.

\section{A történelmi párhuzamok szerepe a történelmi megértésben}

A történelmi párhuzamok értelmezése különlegesen érdekes része a történeti gondolkodásnak. Az iskolai oktatásban is jelentős szerepet kellene kapnia, mert a történelemtudás legadaptívabb részét jelenti.

Az analógiák keresésén alapuló történelmi gondolkodás két típusát különböztethetjük meg. Az egyik esetben a múltban már lejátszódott eseményeket, szituációkat, illetve társadalmi vagy egyéb struktúrákat hasonlítjuk össze egymással. A másikban pedig egy történelmi jelenség megértéséhez az ahhoz valamilyen módon hasonlító mai szituációkat és személyes tapasztalatokat hívjuk segítségül (Drie és Boxtel, 2012). Természetesen ezek az analógiák fordítva is működnek: gyakran elöfordul, hogy éppen a korábbi történelmi példák adnak kulcsot a jelenben lejátszódó eseményekhez.

Vegyük a nemrég Kijevben lezajlott forradalom példáját. Az általános társadalmi elégedetlenség elöször tüntetések formájában felszínre tört, majd a fokozatosan radikalizálódó csoportok áldozatokkal is járó felkelést robbantottak ki, amely végül elsöpörte a fegyveres erőszakot is alkalmazó régi hatalmat. A történelemben sokszor és sok helyen történt már ehhez hasonló. Kérdés, hogy a mai diákoknak az Ukrajnából érkező hírek kapcsán eszébe jutottak-e történelmi párhuzamok, és felidéződött-e az ezekröl tanultakból valami olyan, amit hasznosítani tudtak ennek az új eseménynek a megértéséhez.

Hogyan lehet növelni az esélyét annak, hogy a tanulók gondolkodását a lehetséges történelmi párhuzamok hatékonyan támogatni tudják? A legfontosabb tanács az lehet, hogy a történelemtanár nem bízza a véletlenre, hogy a történelemórákon tanultak és az aktuális események között a diákok képesek legyenek érdemi kapcsolatokat találni.

A probléma tudatosítására azért van szükség, mert az előzetes tervezésen sok múlik. Példánknál maradva az 1956-os forradalom és szabadságharc tanítása nagyon jó lehetőségeket ad a modernkori forradalmak megértéséhez. Jelentősége folytán a tanítására viszonylag sok idő jut. Ez is kedvez annak, hogy kellő részletességgel mutassuk be a diákjainknak ahhoz, hogy az eseményekböl általánosabb következtetéseket is le tudjanak vonni, és ezeket aztán más alkalommal is elő tudják hívni.

Melyek az 56-os forradalom azon jellegzetességei, amelyek felidézése hasznos lehet a hasonló események megértéhez? A személyes szabadság megsértése és az életkörülmények romlása egyaránt fontos szerepet játszhat a hatalom elleni lázadásban. A forradalom kitörésének hosszú gazdasági és politikai folyamatokra visszavezethető általános és véletleneken is múló közvetlen okai is vannak. A forradalmi követelések a tömegeket mozgósító közvetlen igények kielégítésén kívül a fennálló hatalom megdöntésére vagy a hatalomgyakorlás módjának megváltoztatására irányulnak. A hatalom engedményekkel és fenyegetéssel próbálja megelőzni a forradalom kitörését. Amikor ez nem sikerül, erőszakot alkalmaz. A túlzottan erőszakos vagy éppen erélytelen fellépés az első akciókkal 
szemben a hatalom ellen lázadók tömegtámogatásának növekedését és radikalizálódását okozhatja. A tömeges eröszak sikertelen alkalmazása a hatalom politikai és erkölcsi bukásával jár. Az emberek az átélt események hatása alatt cselekednek, gyakran sokkal bátrabban viselkedve, mint ahogy azt magukról korábban feltételezték. A fegyveres harc és politikai alkudozás egymással párhuzamosan zajlik, a fegyveres harc alakulása jelentősen befolyásolja a szemben álló felek tárgyalási pozícióját. A nyilvánosság ellenörzése, befolyásolása és manipulációja is döntő fontosságú lehet az események alakulása szempontjából. A nagyhatalmak a maguk érdekei szempontjából mérlegelik a nemzeti forradalmak és felkeléseket, s a nyilvánosságnak szánt állásfoglalásaik gyakran ellentétesek a valódi döntéseikkel. A nemzetközi összefüggések megismerése elösegítheti a hazai események megértését.

Az ukrán és a magyar forradalom összehasonlítása csak egyetlen példa arra, hogy a történelemtanulás milyen sok hasznos tapasztalatot adhat a világban lejátszódó eseményekhez. Ennek azonban az a feltétele, hogy ez a cél ne sikkadjon el a tanítás megtervezésekor és a tanórai munka közben sem.

\section{Miként látják a diákok a múltbéli embereket?}

A történelemtanulás során a diákok a miénktől teljesen eltérő életmódokkal, kultúrákkal és emberi viselkedésekkel találkoznak. Azt is szokták mondani, hogy a múlt megismerése olyan, mint egy egzotikus utazás egy idegen országban (Lowenthal, 1985). Ez teszi érdekessé a történelemórákat, de egyben csapdákat is rejt a tanárok és a diákok számára egyaránt.

Fontos kérdés, hogy milyen képet alkotnak a tanítványaink a régi korok embereiről, és milyen magyarázatokat próbálnak adni e „furcsa idegenek” cselekedeteire. E képzetek között vannak olyanok is, amiknek az irracionalitását ők maguk is érzik, de valahogy mégis befolyásolják a gondolkodásukat. Említhetem a magam példáját is. A száz évvel ezelötti filmeken az emberek mozgása természetellenesen gyors és szaggatott volt. Sokáig nem tudtam emiatt megszabadulni attól a kényszerképzettől, hogy a valóságban is ilyenek lehettek, hiszen „mások” voltak, mint mi. A II. világháborús katonák és események is az én képzeletemben mindig fekete-fehérben jelentek meg, és furcsa volt, amikor az első színes filmfelvételeket láttam ugyanerről. Az ilyen reflexszerűen beugró vizuális tévképzeteket még hosszan lehetne folytatni az oldalazva járó egyiptomiaktól kezdve a mindig mereven bámuló középkori alakokig.

A történelmi témájú játékfilmek éppen az ellenkező hatással vannak ránk. Túlzottan is a saját koruk ideáljait, beszédstílusát és viselkedésmódját vetítik vissza a múltba. Példaként gondoljunk csak arra, hogy gyerekkorunk óta hányféle Robin Hooddal és Petőfi Sándorral találkoztunk a filmekben. Amerikai és kanadai tanulók esetében megfigyelték azt a jelenséget is, hogy minél jobban hasonlított a történelmi filmben bemutatott élet a maihoz, a tanulók történelmileg annál hitelesebbnek tartották az abban ábrázoltakat (Seixas, 1993, idézi: Seixas, 1996).

A hajdan élt emberek cselekedeteinek értelmezésekor kezdetben két egymással ellentétes tévképzet egyszerre van jelen a tanulók válaszaiban. A mai technikai fejlettséghez képest kezdetlegesnek tünő eszközökböl és a brutális kegyetlenkedésekről szóló történetekből a kisdiákok azt a következtetést vonják le, hogy régen az emberek butábbak és erkölcstelenebbek voltak. Úgy élték le az életüket, hogy a legalapvetőbb dolgokkal sem voltak tisztában (Ashby és Lee, 1987). Ezzel párhuzamosan müködik bennük egy másik tévképzet is: a cselekedetek mozgatórugóinak keresésekor a jelenkor gondolkodásmódját és viszonyait vetítik vissza a múltba. Abból indulnak ki, hogy régen is mindenről ugyanúgy gondolkodtak az emberek, mint ma (Seixas, 1993). 
A tanulók gondolkodása persze idővel fejlődik. A többségnek kezdetben eleve nehézséget okoznak az olyan kérdések, amelyek az emberi cselekedetek okaival foglalkoznak. Később, amikor a saját életük során már viszonylag sok tapasztalatot gyüjtöttek össze az emberi viselkedésről, megpróbálják ezekre támaszkodva megmagyarázni a történelmet is. Az már a történelemtanítás minőségétől is függ, hogy képesekké válnak-e az adott kor gondolkodásmódját rekonstruálni, és ezt figyelembe véve próbálják-e meg helyesen értelmezni a dolgokat. A tanulók válaszait vizsgálva Ashby és Lee négy minőségi fokozatot különböztetett meg:

- a múltban élők buták voltak: az emberek nem úgy viselkedtek és gondolkodtak, ahogy mi, mert nem volt még hozzá elég eszük és ismeretük;

- sztereotípiák általánosítása: az emberek mindig ugyanúgy gondolkodnak és viselkednek, függetlenül attól, hogy hol és mikor éltek;

- mindennapi empátia: megérteni a múltban élők érzéseit és gondolatait ugyanúgy lehet, ahogy a környezetükben élökét is megpróbáljuk megérteni;

- korlátozott történelmi empátia: a történelmi kontextusról tanultakat is fel kell használni a hajdan élt emberek cselekedeteinek megmagyarázásához (Ashby, Lee és Dickinson, 1997).

Megfontolandó tanulsága volt Ashby és Lee kutatásainak az is, hogy még a középiskolás tanulók esetében is a döntő lépés az volt, hogy valóságos emberekként tudják elképzelni a történelmi szereplőket. Ez volt az alapvető feltétele annak, hogy értelmes következtetéseket vonjanak le a gondolataikról és a cselekedeteik motívumairól. Ehhez tudták aztán folyamatosan hozzákapcsolni az újabb információkat és ismeretelemeket.

\section{A történelmi empátia fejlesztése}

Az empátia fogalma kettős természetü. Jelenti egyrészt azt a beleérző képességet, amelylyel át tudjuk élni mások érzelmeit, másrészt jelenti azt, ahogy helyzeteket, eseményeket mások nézőpontjából is képesek vagyunk látni.

A mindennapi empátiának is van tehát egy affektív és egy kognitív komponense. A pszichológusok szerint empátiás képességünk e két oldala nem együtt és nem ugyanúgy fejlődik. Azt feltételezik, hogy a szülői mintáknak is szerepe van, mégpedig úgy, hogy az anya az érzelmi, az apa pedig a kognitív oldal szempontjából meghatározóbb (Miklikowska, Duriez és Soenens, 2011). Persze ez a hatás a valóságban azért nagyon sokféleképpen össze is keveredik. Így nézve a dolgot az iskolában hasonló szerepmegosztás lehetséges az irodalom- és a történelemtanítás között.

A történelemtanárok nem egyszerüen az empátia, hanem a történelmi empátia fejlesztéséről beszélnek, bár legtöbbször a gyakorlatban egyszerüen csak a diákok érzelmi beleérző képességét igyekeznek mozgósítani a történelemórákon is. Általában azzal a helyes pedagógiai szándékkal, hogy a diákokat érzelmileg is érintse meg az, amiről tanulnak. Érezzenek sajnálatot és szolidaritást a szenvedést és elnyomást átélő emberek iránt, vagy azonosuljanak a hazáért, igazságért, szabadságért küzdő hősök lelkesedésével és elszántságával. Érdemes átgondolni, hogy ehhez képest mennyiben más az, amit már valóban történelmi empátiának nevezhetünk.

A történelmi eseményekröl készülő magyarázatok fontos részét képezi annak megválaszolása, hogy a korabeli emberek döntéseit és cselekedeteit mi motiválta. Ehhez a múlt kutatójának nézőpontot kell váltani. Úgy kell új összefüggéseket találva értelmet adnia a történéseknek, hogy megpróbálja a dolgokat úgy látni, ahogy azt a korabeli emberek látták (Lee, Ashby és Shemilt, 2005). Ehhez elöször is „el kell felejteni” mindent, amit az akkori emberek még nem tudhattak. Ez nemcsak a később lejátszódott eseményeket 
jelenti, hanem az olyan ismereteket és információkat is, amit akkor még csak kevesen tudhattak, vagy amit a többség elöl eltitkoltak. Vagyis a valódi történelmi nézőpontváltás nemcsak a gondolkodásunk tudatos megfegyelmezését, hanem további kutatómunkát is igényelhet. Hiszen azt, hogy mit tudhattak és mit nem a korabeli emberek bizonyos eseményekröl, csak úgy tudjuk kideríteni, ha ezt a kérdést külön is alaposan megvizsgáljuk. Ugyanez érvényes arra is, amikor a korabeli emberek fejével akarunk gondolkodni. Ahhoz, hogy megértsük a véres polgárháborúkhoz vezető vallási fanatizmust, nem elég felfüggeszteni magunkban a mai kor vallási türelmet követelö erkölcsi értékrendjét. A valódi válaszokhoz elöször fel kell tárnunk a korabeli intézmények müködését, meg kell ismernünk a mindennapi életet alakító társadalmi szokásokat, rekonstruálnunk kell ez egyes emberek döntéseit meghatározó prioritásokat.

A történelmi empátia fejlesztése tehát nem merülhet ki egyszerü szerepjátékokban. Igazából azt kell megtanítanunk a diákoknak, hogy a korabeli emberek gondolkodásmódjának rekonstruálása is a történelemtudomány szabályai szerint történik. Elöször a feladatnak megfelelő forrásokat gyüjtünk, ezekből következtetünk, végül az állításainkat a forrásokban található részletekkel bizonyítani próbáljuk.

A történelmi empátia nem nélkülözheti a nyitott érzelmi beállítódást, de elsősorban az empátia kognitív oldalának gyakorlását jelenti.

\section{A képzelőerő szerepe a történelmi gondolkodásban}

A történelmi gondolkodást meghatározhatjuk úgy is, mint a történelmi múlt feltárásához és interpretálásához szükséges intellektuális képességek sajátos együttesét. A történelmi képzelet ebbe bizonyosan beletartozik.

A képzelőerő a történelmi kutatómunka elengedhetetlen összetevője. Enélkül nem lehet következtetéseket levonni a múltban élt emberek leghétköznapibb tevékenységeiről sem, nem beszélve a viselkedésükről, gondolkodásukról és érzéseikről (Capita, Cooper és Mogos, 2000). Számos kutató a deduktív érvelés és a képzelőerőre támaszkodó gondolkodás állandó együttmüködését emeli ki a történelmi gondolkodás meghatározó sajátosságaként. Aki rendelkezik történelmi képzelőerővel, az képes például arra, hogy egyszerre sokféle lehetőséget is elképzelve, rendkívüli részletezettséggel maga elé tudja idézni, hogy bizonyos tárgyakat hogyan készítettek el és használtak a múltban. Aztán erre támaszkodva következtetni próbál a tárgyakat készítő és használó emberek életének egyéb sajátosságaira is. Számomra a legszebb példái ennek László Gyula honfoglaláskorral foglalkozó munkái. Az ő egyik kedvenc kifejezése a „termékeny bizonytalanság” volt. Ez arra a kutatói tudatállapotra is utalt, amikor bizonyos leletek alapján a régész képzelete már beindul, és a valóság különböző lehetséges képeit villantja fel, hogy aztán ezek között megtalálja azokat, amelyeket az aprólékos kutatómunka eredményei is valószínüsítenek, de teljességgel sohasem bizonyíthatnak.

Ha a képzelőerő a történelmi gondolkodás fontos összetevője, akkor ennek fejlesztésére a történelemtanításban is gondolnunk kell. Akár úgy is, hogy ennek jelentőségét már a tanulás kezdetén tudatosítjuk tanítványainkban egy-egy ilyen gondolat bemutatásával:

„...a múlt nem azonos azzal, ami megmaradt belőle. Nagyrészt csak a szilárd anyagokból való tárgyak vagy a nyelvi emlékek maradtak meg, az érzelmi, lelki mozzanatok a semmibe enyésztek. Mi megkíséreljük feleleveníteni azt is, ami feledésbe merült, mert enélkül a múlt nem élet, legfeljebb csak technika- és eseménytörténet." 
„Húsz esztendőmbe került, mire odáig jutottam, hogy ne csak azt lássam meg, ami a földben van, hanem azt is, ami a föld felett - lehetett, csak nyoma, emléke, látszólag nem maradt. Pedig e »nincs« is »láthatóvá« válhat, csak igen-igen kifinomult módszerekkel, eszközökkel kell közeledni hozzá. [...] S nagyon hosszú, lassú, csapdákkal, tévedésekkel teli úton kellett végigbukdácsolnom, mire megtudtam: az is valóság, amit nem látok.” (László, 1988)

\section{Irodalomjegyzék}

Ashby, R. és Lee, P. J. (1987): Children's concepts of empathy and understanding in history. In: Portal, C. (szerk.): The history curriculum for teachers. Falmer Press, London.

Ashby, R., Lee, P. és Dickinson, A. (1997): 'How children explain the why of history'. Social Education, 61. 1. sz. January, 17-21.

Barca, I. (1997): Adolescent ideas about provisional historical explanation. (Portuguese translation for publishing at CEEP.) Universidade do Minho, Braga, Portugal.

Capita, L., Cooper, H. és Mogos, I. (2000): History, Children's Thinking and Creativity in the Classroom: English and Romanian perspectives. International Journal of Historical Learning, Teaching and Research, 1. 1. sz.

Drie, J. van és Boxtel, C. van (2008): Historical Reasoning: Towards a Framework for Analyzing Students' Reasoning about the Past. Educational Psychology Review, 20. 2. sz., June. 87-110. DOI: 10.1007/ s10648-007-9056-1

László Gyula (1988): Árpád népe. Helikon, Budapest.

Lee, P. J., Ashby R. és Shemilt, D. (2005): Putting principles into practice: teaching and planning. In:
Donovan, S. M. és Bransford, J. D. (szerk.): How Students Learn: History in the Classroom. National Academies Press, US National Research Council, Washington DC. DOI: $10.17226 / 11100$

Lee, P. J. és Ashby, R. (2000): Progression in historical understanding among students ages 7-14. In: Seixas, P., Stearns, P. és Wineburg, S. (szerk.): Teaching, Learning and Knowing History. New York University Press, New York.

Lowenthal, D. (1985): Past is a Foreign Contry. Cambridge University Press.

Miklikowska, M., Duriez, B. és Soenens, B. (2011): Family Roots of Empathy-Related Characteristics: The Role of Perceived Maternal and Paternal Need Support in Adolescence. Developmental Psychology, 47. 5. sz. 1342-1352. DOI: 10.1037/a0024726

Seixas, P. (1993): Popular film and young people's understanding of the history of Native-white relations. The History Teacher, 3. sz., May. 351-370. DOI: $10.2307 / 494666$

Seixas, P. (1996): Conceptualizing the Growth of Historical Understanding. In: The Handbook of Education and Human Development. Blackwell Publisher, Oxford. 10.1111/b.9780631211860.1998.00034.x

\section{Jegyzetek}

${ }^{1}$ http://mek.oszk.hu/00800/00893/html/

2 http://www.kossuth.hu/index.php?o=konyvek\&k=1649 